Brown, Nina, Marcel LaFlamme, and Sarah Lyon. 2018. "What Happened, or, Impasses and Future Horizons for an Open Anthropology of Work." Anthropology of Work Review 39, no. 1: 44-47. https://doi.org/10.1111/awr.12137.

\title{
What Happened, or, Impasses and Future Horizons for an Open Anthropology of Work
}

\author{
Nina Brown \\ Community College of Baltimore County \\ Marcel LaFlamme \\ Rice University \\ Sarah Lyon \\ University of Kentucky
}

These words were never supposed to be stuck behind a paywall. That is, this editorial was to have welcomed you, our readers, to the first open-access issue of the Anthropology of Work Review. ${ }^{1}$ The fact that we cannot extend such a welcome means that we owe you an explanation. We offer it to ensure that the story does not get lost in buried email threads, but becomes part of the published record that can be consulted by future historians of the discipline. We offer it to inform advocates of open access in other disciplines of the challenges that they, too, may face by operating within the strictures of a larger scholarly society. We offer it to register our disappointment at the outcome of a four-year process that, for all of the urgency that set it into motion, ended up largely reproducing the status quo. Yet we also offer it as a token of our continued commitment to innovating open futures for the anthropology of work, at a time when the simultaneous intensification of demands on workers and the attenuation of protections for them demand wider engagement with this vital field of inquiry. 


\section{HOW WE GOT HERE}

In November 2013, the Executive Board of the American Anthropological Association (AAA) adopted a series of recommendations aimed at shoring up the sustainability of the Association's publishing program. Perhaps most noteworthy, at the time, was the decision to embrace digital publication as the default format for AAA journals, with print copies to be available on-demand and at additional cost. But the Executive Board also charged sections of the AAA with developing a five-year sustainability plan for the journals they sponsored. The Board created a Publishing Oversight Working Group (POWG) to review and assess these plans in terms of their alignment with four publishing values: quality, breadth, accessibility, and sustainability. Beyond reducing expenses, sections were encouraged to "reach for creative visions and possibly to consider or expand on the current AAA open-access experiments" (Schmid 2014). More ominously, the AAA indicated that journals whose sustainability plans were found wanting by the POWG would be dropped from the service-level agreement and asked to self-publish. $^{2}$

Sitting down to write a sustainability plan for the Anthropology of Work Review in early 2014, then-editor Sarah Lyon faced a daunting task. The journal was one of five singled out by the AAA as "vulnerable" in light of relatively low submission rates and usage statistics. With production costs projected to keep rising even as library subscriptions declined, the Society for the Anthropology of Work (SAW) was faced with the prospect of spending all of its dues

revenue just to keep the journal afloat. Some of the options presented to SAW included merging the journal with another title or finding another section to cosponsor the journal, but neither of these options appealed to SAW members, who felt that taking those steps would dilute the journal's distinctive topical focus. However, SAW members were receptive to the idea of taking 
the journal open-access, in hopes of both cutting costs and reaching broader publics_-including labor movements - that would not otherwise have access to its output.

Accordingly, Lyon prepared a sustainability plan that proposed a self-publishing model for the Anthropology of Work Review, under which the journal would be published on an openaccess basis to a website maintained by SAW and would also be included in AnthroSource. The peer-review process that underpins the quality of the journal would remain unchanged, although some sacrifices would be made on the production side by foregoing professional typesetting. Lyon submitted the plan on SAW's behalf in July 2014, and the POWG invited (but did not require) a revision of the plan in response to its detailed feedback. Meanwhile, Lyon was offered the opportunity to serve as editor of Human Organization, the journal of the Society for Applied Anthropology, initiating a search for a new editor of the Anthropology of Work Review. In the midst of this editorial transition, the POWG's enthusiasm for self-publishing seemed to cool, with a November 2014 memo underscoring that it was "not encouraging sections to self-publish" and with renewed efforts to engage with SAW about staying in the service-level agreement. But Nina Brown, who was named the journal's new editor in early 2015, first wanted to see where SAW's board and members stood; accordingly, she invited member feedback at a public forum on the future of the Anthropology of Work Review, and she brought the issue back to the board for a formal vote. The consensus on both fronts was to move ahead with open access, which incoming SAW president Jan English-Lueck characterized as "a matter of principle for this organization."

The SAW board formed a steering committee to oversee the open-access transition, which included Marcel LaFlamme, one of the board's two student representatives and the managing editor of the AAA's only other open-access journal, Cultural Anthropology. Having 
seen the challenges facing a true self-publishing operation firsthand, LaFlamme encouraged SAW to consider partnering with a library publisher to enhance the discoverability of journal content and to avoid the ongoing cost of upgrading web infrastructure. By 2016, an annually updated directory of library publishers included 115 libraries that collectively published more than 800 journal titles. And while library publishers had traditionally focused on student- or faculty-led publications based at their institutions, a growing number were forging relationships with external stakeholders including scholarly societies (Jones 2014). SAW agreed to send LaFlamme to the 2016 Library Publishing Forum in Denton, Texas to learn more about this segment of the publishing landscape and to identify some potential partners. Here, it is worth noting that, in its November 2014 memo to sections, the POWG indicated that "a title that elects to self-publish could conceivably consider a publishing contract." In other words, while SAW's foray into library publishing did mark a departure from its original sustainability plan, it was nonetheless consistent with the guidelines promulgated by the AAA.

Initial conversations with four library publishers, which focused on the range of services that the programs could provide and their associated costs, prompted SAW to zero in on the Ohio State University (OSU) Libraries. OSU's program was poised to grow and it was actively seeking new external partners. The services it could offer included a hosted instance of Open Journal Systems, an open-source publishing platform, as well as support for the creation of digital object identifiers and for indexing in scholarly databases. Given SAW's lean budgetary situation, the fact that OSU was offering these services free of charge was an attractive offer indeed. With OSU faculty member Nicholas Kawa generously serving as our institutional sponsor, SAW submitted a formal application to the OSU Libraries in October 2016, which was approved in time for the AAA annual meeting the following month. The SAW board voted to 
move ahead with the partnership, and we all breathed a sigh of relief at the thought that we had delivered the Anthropology of Work Review to a safe harbor.

Or had we? While at the annual meeting, Brown, English-Lueck, and LaFlamme met with Janine Chiappa McKenna, who had joined the staff of the AAA as the new director of publishing in March 2016. As we started to discuss the details of partnering with OSU, one sticking point that emerged was the copyright status of published articles. The AAA's standard author agreement effects a transfer of copyright from the author to the AAA, which allows the AAA to manage permissions requests on behalf of the author and to take action in cases of copyright infringement. But OSU, like many library publishers, prefers to have authors retain copyright to their published work and then make it accessible under an open license like the ones devised by Creative Commons. At the end of the meeting, we resolved to continue discussions about how to reconcile these approaches, which seemed doable given the POWG's 2014 statement that "of course the [AAA author] agreement would be modified to support the sponsoring section's approach to self-publishing."

In the weeks that followed, though, little headway was made; neither side was willing to budge on the copyright transfer issue, and by March 2017 it was clear that we were not going to reach an agreement. After months of planning, we were back to square one. With just nine months to go before the AAA's existing agreement with Wiley-Blackwell elapsed and the Anthropology of Work Review found itself without a publisher, it was time to get creative. Brown asked Mary Beth Schmid, who had recently joined the SAW board, to take on the role of assistant editor, adding capacity to the editorial team. LaFlamme drew up a list of commercial service providers that could host the journal, but it quickly became clear that the hosting fees were more than SAW could pay on top of our other production costs. We needed a partner, not a 
vendor: an organization that saw supporting the Anthropology of Work Review as consistent with its mission and that was willing to accommodate the AAA's requirements.

In May 2017, the steering committee decided to pursue a partnership with another library publishing program, this time at Indiana University (IU). The IU Libraries are widely known for their support of open scholarship through initiatives like Open Folklore, and they had recently partnered with Cultural Anthropology on a multimedia publishing initiative. In response to our query, the Libraries' publishing program indicated that it was willing to host the journal and to comply with the AAA's conditions about transferring copyright and using a nonstandard open license rather than Creative Commons. We were even invited to participate in a joint endeavor between the IU Libraries and Indiana University Press, under which the Press would help to promote the Anthropology of Work Review and to provide some initial design services - all free of charge! We were amazed by the level of investment that IU was willing to make in our journal; now, we just needed the AAA to approve the partnership.

A conference call with AAA staff in June went well and plans were made to draw up a memorandum of understanding. The one lingering issue was what would happen to journal content published under the partnership with IU if, at some point in the future, SAW moved on to a different publisher. IU's standard hosting agreement held that the university "reserves the right to make the content accrued during the time of this agreement available to users." Retaining the content was important to IU because it would be providing an extensive set of services free of charge, which it saw as a mission-driven investment in making the content permanently available. Citing the precedent of its portfolio-scale agreements with previous publishing partners, though, the AAA wanted all of the content returned upon the termination of the partnership. On another call in August, we proposed a compromise: if the partnership ended, IU 
would take down its hosted instance of the Anthropology of Work Review, making it clear that IU was no longer the journal's publisher of record, but would archive the content in its institutional repository on a nonexclusive basis so that the content would remain openly accessible at no cost to SAW or the AAA. The AAA rejected this compromise, as well as a subsequent offer to return the content as long as the AAA committed to keeping it openly accessible somewhere else. The AAA did offer to allow IU to retain the content for twenty years after the termination of the partnership, whereupon the content would need to be remanded to the AAA with no further guarantees about its accessibility. But IU rejected this proposal, pointing out that a basic condition of open-access publishing is a commitment to making content open in perpetuity.

By early September, it became clear that we were not going to get to yes. SAW was presented with two options: we could self-publish the Anthropology of Work Review on our AAA-hosted WordPress site, or we could join the new service-level agreement with Wiley and forget about open access. Neither of these options felt like a good one. Publishing the journal on SAW's basic website would be both expensive and labor-intensive, and the articles would likely be lost in the sea of online information without the help of a publishing partner to keep the openaccess version of our journal discoverable. Yet the prospect of retreating behind a paywall was a painful one after having made a public commitment to open access. After weighing our options, the steering committee recommended that the SAW board approve rejoining the service-level agreement, which it did in October 2017. 


\section{WHERE WE GO NEXT}

With the benefit of some critical distance from the events described above, we as social scientists have wanted to move past our personal feelings of frustration to reflect on the institutional context that gave rise to this outcome. We found ourselves returning to the questions raised by Chris Kelty and colleagues a decade ago (Kelty et al. 2008) about the changing conditions of knowledge production and their implications for scholarly societies like the AAA. As digital tools have made it possible to produce, distribute, and validate scholarship in new ways, the AAA has remained beholden to a business model organized around scarcity: some people get to read our publications, and some don't. ${ }^{3}$ The paywall, to put it bluntly, is a form of coercion used to extract the revenue the AAA needs to keep the lights on. But has anyone stopped to ask stakeholders like libraries if there are other ways of supporting the important work that scholarly societies do? Are our structures and processes of governance set up in such a way that fundamental questions like this could even surface? How have these structures contributed to what we see as a condition of learned helplessness, such that the world's largest association of anthropologists can no longer imagine how to conduct its affairs without the backing of a commercial publisher?

These are big questions, and answering them fully is beyond our scope here. What we can say is that we see the decision to scuttle not one, but two partnerships with library publishers as a missed opportunity for the AAA to learn more about a possible path forward. The risks to the Association were minimal; it is remarkable to think that the agreement with IU was blocked over the possibility of monetizing the Anthropology of Work Review's backfiles twenty-five years from now, given that a pessimistic assessment of the journal's value and staying power was 
what led SAW down the path of self-publishing in the first place! Looking back, we see inflexibility, incuriosity, and a desire for absolute control over published content on the part of our parent organization as the chief causes of SAW's stymied open-access transition. These postures, we argue, are incompatible with the values of quality, breadth, accessibility, and sustainability that the AAA's publishing program aims to uphold.

Yet those of us who feel a greater affinity with our sections than with the AAA as a whole must also acknowledge our complicity with the current state of affairs. AAA leadership often assumes that what sections want from the Association's publishing program is to maximize revenue flowing to sections, while minimizing fuss for journal editors. And can we really say that they are wrong? How many section leaders had any trouble finding a use for the onetime "signing bonus" that sections received upon the renewal of the Wiley agreement? The fact is that all of us have become addicted to the royalties paid out by a commercial publisher like Wiley, while ignoring the costs of this relationship for our home institutions and for the broader ecology of scholarly communication. So, inspired by the insights of the multidisciplinary scholarship on degrowth (e.g., Kallis 2018), we propose to ask: could we as an association live with less? How much less could we live with, if that meant being part of the solution rather than part of the problem? Might letting go of our preoccupation with more lay the groundwork for modest, collaborative modes of living in common?

These are the questions that SAW has committed itself to taking up in the months ahead. We will continue to participate in Libraria, an open-access cooperative of journals and scholarly societies that has attracted the support of research libraries at institutions like Duke and MIT. We will begin publishing short-form web content on the SAW website, which will be owned by authors and openly licensed, in order to accelerate the exchange of ideas between anthropologists 
of work and their interlocutors. We will also initiate a deliberative process of discerning whether our broader publishing activities are aligned with the needs of the section and the scholarly community it serves. There are some among us who believe that the section should redirect its energies toward supporting a new open-access journal that would not be owned or controlled by the AAA. Others feel that SAW should continue to focus on the Anthropology of Work Review and on strengthening its position within the AAA portfolio. These debates - and the many other activities that make up the intellectual life of the section — make it an exciting time to be a member of the Society for the Anthropology of Work, and we invite you, our readers, to join us as we chart our future course.

\section{NOTES}

1. SPARC, a member-based organization of academic and research libraries, defines open access as "the free, immediate, online availability of research articles combined with the rights to use these articles fully in the digital environment." For a more extended introduction to open access, see Suber (2012).

2. In emails sent to section leadership on December 6, 2013 and July 1, 2014, then-Director of Publishing Oona Schmid wrote that "if the Publishing Oversight Working Group finds these plans unfeasible to meet the values of the publishing program ... sections will be asked to selfpublish starting in 2018."

3. The AAA often promotes its participation in philanthropic initiatives that provide free or lowcost access to institutions serving underserved communities. Such initiatives are worthy gestures, but they mask gaps in access that remain at institutions like community colleges, which serve more than one-third of the undergraduate students in the United States today. At the Community College of Baltimore County, where one of us (Brown) teaches, AAA journals are subject to an eight-year embargo because the library cannot afford access to the most current scholarship. 


\section{REFERENCES}

Jones, Phill. 2014. "What's Going On in the Library? Part 1: Librarian Publishers May Be More Important than You Think." Scholarly Kitchen, December 1. Accessed March 5, 2018. https://scholarlykitchen.sspnet.org/2014/12/01/whats-going-on-in-the-library-part-1librarianpublishers-may-be-more-important-than-you-think.

Kallis, Giorgios. 2018. Degrowth. Newcastle, UK: Agenda Publishing.

Kelty, Christopher M., Michael M. J. Fischer, Alex "Rex” Golub, Jason Baird Jackson, Kimberly Christen, Michael F. Brown, and Tom Boellstorff. 2008. "Anthropology of/in Circulation: The Future of Open Access and Scholarly Societies.” Cultural Anthropology 23, no. 1: 559-88.

Schmid, Oona. 2014. “Getting to Journals 3.0.” Anthropology News, March 3.

Suber, Peter. 2012. Open Access. Cambridge, MA: MIT Press. 